\title{
UHF テレビジョン放送について
}

\author{
郵政省電波監理局 田中 真 三 郎
}

\section{UHF テレビジョン放送局の現状}

わが国のテレビジョン放送局用周波数としては, VHF 帯の 12 チャネルおよび UHF 帯の 18 チャネル, 合計 30 チャネルが割り当てられて抢り，そのうち VHF 帯 は親局用抢よび中継局用に，また UHF 带はもっぱら 中継局用に利用されている. 現行の割当計画はVHF 帯 チャネルの使用を基本とし，VHF チャネルによっては 計画しえない場合に限り UHF 帯チャネルを使用するこ ととし, かつ, UHF チャネルと VHF チャネルを同一 地区で使用しないような基本方針となっている.

てのような方針の下で，昭和 42 年 6 月現在に沶壮る $\mathrm{U}, \mathrm{V}$ の使用別をみると, 予備免許中の局を含むテレビ ジョン総局数 1674 局のうち，ちょうど 3 分の 1 にあた る 553 局は UHF 局である. てれら UHF 局によるカ バレージ内世帯数は 264 万（昭 42.3 末）にすぎない が，てれらの局を受信するコンバーター受信機数は 55 万台であって，しか屯急激に增えてきている.

てれら UHF 局の模様を外国についてみると，アメ リカではテレビジョン総局数 500 局（トランスレーター 局を除く) のうち UHF 親局は約 100 局を数え, 1962 年 7 月のいわゆるオールチャネル法制定，1964年 4 月30 日の施行以来, 日本のメーカーがアメリカに輸出したカ ラーを含む全チャネル用受像機台数は 380 万台に及えで いるという、ヨーロッパ諸国もまた U・V 混在方式を とるとのととで，EBU 会議がきめたヨーロッパ全地域 飞対するチャネルプランによれば，VHF 局の約 1,000 局に対し, UHF チャネル局は 4,500 局の多きに及ん でいる.

\section{UHF 帯チャネルの得失}

テレビジョン用周波数帯としての UHF 带チャネル をVHF とくらべた場合, 誰あがあげる欠点として受 像機の問題と電波伝搬特性がある. UHF 局を受信する

\footnotetext{
"UHF Television Broadcasting in Japan" by Shinzaburo Tanaka (Radio Regulatory Bureau, Ministry of Posts and Telecommunications, Tokyo)
}

ためには，コンバーターの付加，あるいはオールチャネ ル受像機が必要だというととは，UHF チャネル自体の あつ欠点というよりはむしろ過渡的なものであり，やが ては解決される問題であることを見逃してはなるまい。 物の背後までまわり込む回折の特性が VHF チャネル にくらべて劣るという点に着目するならば，できる限り 少ない置局数で山岳などあ含む広い地域をカバーじうう とする，主としてテレビジョン放送開始の初期の考え方 からみ机ば，明らかに年とみられるものであるが，あ る限定した放送対象地域をカバーしようとする場合に は，必ずしあ欠点とはされない。

一方，UHF 帯チャネルの長所としては，(1)チャネ ル数が多くとれ，すべてをテレビジョン用として使用す るならば計算上は 50 チャネルとなる．（2）自動車雑 音，ウェルダー妨害などが著しく少なく，妨害を受ける ことがほとんどない（（3)受信アンテナ素子としては， 鉛筆ぐらいの長さのきわめて短いものですみ，取扱いが 容易である. 受像品位劣化の相当の原因がアンテナ設置 の不良によるととを考え机ば，乙の点は高く評価されよ う.（4）一般にゴーストが少なく，きれいな画面が得ら れるといわれている，以上の長所は，今後のカラ一放送 の普及，秩序ある放送体制の確立という見地加ら考える となかなかの長所といえよう.

他方，今日のテレビジョン放送の繁栄に主役を演じた VHF 寡にも，いろいろとなやみや限界がみえてきた。

（1）なんといってもチャネルの絶対数が少なく，12于ャ ネルでは民放番組の複数化の要望に応じえなくなってき た（2 )放送局数がきわ奴多くなったてと，スポラ異 常伝搬などによるテレビ局相互の混信が問題之なってき たとと. (3) VHF 帯の第 3 チャネルと第 4 チャネルの 間では多くの陸上移動局，航空無線航行局などが運用さ れており，乙れらの局とテレビジョン局との間でイメー ジ妨害，混変調妨害などの問題がようやくやかましくな ってきた。

ちなみに，去る 3 月でいわゆる第一次，第二次プラン の置局を完了したが，乙れらの実施にあたって，計画表 
では VHF チャネルの使用を予定しながら，主として 上記(1)の理由から，実際にはUHF チャネルまたは予 定外の VHF チャネルに変更した数は 90 チャネルに あ及んだてとを付記しておてう。

\section{UHF 帯テレビジョン放送の 技術基準}

昭和 33 年以来, 郵政省電波技術審議会を中心として 検討が進められ，(1)送信設備基準（送信機出力，スプ リアス輻射の許容値, 周波数安定度および送信用空中 線)，( 2 )受信設備基準 (シングルスーパーおよびダブル スーパー両方式受像機についての中間周波数, スプリア ス輻射の許容值, 隣接チャネル妨害特性, 局発周波数の 安定度扰よび受信用空中線の特性), (3) 電波伝搬特性お よびチャネルプラン策定基準（見通し内郊外伝搬特性, 中小・大都市減衰量, 山岳背後の電界強度推定, エコ 一, 偏波面効果, 最小所要電界強度扔よびチャネルセパ レーション) などについて重要な答申あるいは中間報告 が行なわれた．とれらの審議は当初は比較的小範囲の地 域で， 470〜 770 MHz のうちの約 $100 \mathrm{MHz}$ を使用する という前提によって始められたあのであったが，昭和 37 年度加ら大電力放送に関する事項も含められたの であった。

上記の各項目は今後の UHF 帯テレビショョン放送に とっていずれあ重要な意味をもつあのであるが，大電力 用送信管については，すでに $10 \mathrm{~kW}$ 級のものがクライ ストロンで国産されており， $50 \mathrm{~kW}$ のものについてあ 開発中であるとの中間報告（38年度）は, 最小所要電界 強度に関する 37 年度答申（画像品位 4 の聴視状態を得 るには UHF 帯では $70 \mathrm{~dB}(3 \mathrm{mV})$ の電界を必要とする との結論）とあいまち, さらにまた, 利得 $10 \sim 15 \mathrm{~dB}$ を期待しうる UHF 水平偏波用送信空中線の開発に関す る答申 (35 年度) などとともに, 今後の UHF 新親局 の規模の想定に重要なめどを与えるものであり，同一地 点から送信する場合, UHF 局の送信規模は VHF 局に くらべ約 10 倍と考えてよかろう.

また, 幾多の論議を経て, オールチャネル受像機の映 像中間周波数として $58.75 \mathrm{MHz}$ (音声中間周波数は $54.25 \mathrm{MHz}$ ) が選定されたととも, チャネルプラン策定 上，特に重要な答申であったといえよう.

\section{4. チャネルプラン策定上の考慮事項}

上記 3 章にのべた答申の技術的基準に基づいて, 新し いUHF 帯テレビジョンチャネルプランを策定すると
すれば，たとえば下記のような実際的考慮が必要となろ う.

（1）放送区域の決定，（2）特定放送区域内放送事業 者数あるいは番組数の決定，（3)上記（1)，（2）の一時 的または将来的要求を実現するための, 一時的かつ長期 的チャネルとチャネル数の推定，（4)秩序正しいチャネ 儿配列表の決定, (5)送信場所, 送信機電力および実効 輻射電力の想定と, 電波放送区域の推定，(6)同一チャ ネル混信の排除（放送区域全域において $S / I=40 \mathrm{~dB}$ を 確保するための電界強度計算を行なう)，（7）隣接チャ ネル混信の排除（同一放送区域の 2 局以上の局に対して はもちろん，放送区域を異にするも一部重複する場合で あって, かつ, 番組系統の異なる 2 局以上の局に対して は，原則として隣接チャネルは割り当てないよう計画す る)，（8）イメージ妨害関係チャネルの使用制限（放送 区域が同一または重複する 2 局以上に対して，互いに士 19 チャネル関係になるチャネルーたとえば，39 チャネ ルと同一地区には 20 チャネルあるいは 58 チャネルは 原則として割り当てない), (9) 局発輻射関係チャネル の使用制限（新しい中間周波数を用いた受像機の場合， たとえば，18 チャネルと 27 チャネルが同一地区にある と, 18 チャネル受信者の局発輻射が 27 チャネル受信者 に妨害を与えることがある)，(10)既設 UHF 中継局に 対する影響の推定（既設 UHF 局のなかには，た之え ば 45, 48,51, 54 および 57 チャネルを使用しでいる場 所があり， 45 と 54 , また 48 と 57 は互いに局発輻射 関係にあるが，てれはすでに(9)にあげたひとつの原則 にあわないあのであるが,すでに 500 局あまりあるUHF 中継局に対する影響をなるべく考慮して，新プランをた てることが望ましい)，(11）電波天文業務など他の業務 の局に対する配慮（テレビジョンチャネルの 36 番にあ たる $610 \mathrm{MHz}$ 近傍は，世界的にあ電波天文業務用周波 数というととになっており，てれらは相当の間テレビジ ヨン用に使用することはさけるべきであ万う)，(12）放 送衛星その他の将来の技術の進歩に対処するための周波 数帯の一部留保.

\section{5. むす び}

地域格差是正の要望はようやく大きく, 新局申請者数 む 150 社をてえている.オールチャネル受像機む試作の 段階をへて，市販するメ一カーも出てきた. 5 年〜 7 年 ぐらいで相当数の VHF 受像機は買い換えられようとの NHKあるいは電子機械工業会の予測む出ている. UHF テレビジョン時代はもうそてに来ているといえよう. 